\title{
Specific TP53 mutations predict aggressive phenotype in head and neck squamous cell carcinoma: a retrospective archival study
}

\author{
Jenni K Peltonen ${ }^{1} 2^{*}$, Kirsi H Vähäkangas ${ }^{3}$, Henni M Helppi ${ }^{1}$, Risto Bloigu ${ }^{4}$, Paavo Pääkkö ${ }^{5}$ and \\ Taina Turpeenniemi-Hujanen ${ }^{1}$
}

\begin{abstract}
Background: Head and neck squamous cell carcinoma (HNSCC) is the sixth most common malignancy in the world in developed countries. Despite the intense research in the area of squamous cell carcinomas of head and neck (HNSCC), long-term survival rate has not changed significantly in this malignancy during recent decades.

Methods: In this study, we focused on TP53 mutations in specific regions, including DNA-binding surface, to determine whether mutations at specific locations of TP53 could be used to help in setting up prognosis and response to therapy of head and neck squamous cell carcinoma patients. We analysed TP53 mutations in 46 HNSCC by PCR-SSCP and sequencing and characterized how different TP53 mutations affect the patient outcome.

Results: Tumours containing TP53 mutations in DNA-binding regions (L2, L3 and LSH motif) had a significantly poorer prognosis and response to radiotherapy than tumours outside those regions. Disease-specific 5 -year survival of patients with TP53 mutations affecting DNA contacts was $43.5 \%$ while it was $77.8 \%(p<0.05)$ in patients with TP53 mutations in other residues not involved in DNA contact. Moreover, nodal metastasis were more prevalent (although not statistically significantly) with TP53 mutations in DNA-binding surface regions. We noticed that the patients with TP53 mutations in L3/LSH motifs had a significantly poorer response (11.4\% responding) to radiation than the patients with a wild type p53 (48.6\%) or TP53 mutations outside the DNAbinding regions $(40 \%)(p<0.05)$.
\end{abstract}

Conclusions: These data indicate that a TP53 mutation in L2, L3 or LSH is worth pursuing as a marker for predicting prognosis and response to radiation among HNSCC patients.

\section{Introduction}

Head and neck squamous cell carcinoma (HNSCC) is one of the 10 most frequent malignancy in the world and more than 500000 new cases are reported annually [1]. Despite the intense research in the area of squamous cell carcinomas of head and neck (HNSCC), the long-term survival rate has not changed significantly in this malignancy during recent decades [2]. The initial treatment approaches for a patient with HNSCC include most often radiotherapy added to primary surgery one way or another or as a definitive treatment of inoperable

\footnotetext{
* Correspondence: jenni.peltonen@oulu.fi

'Department of Oncology and Radiotherapy, Oulu University Hospital,

University of Oulu, Oulu, Finland

Full list of author information is available at the end of the article
}

disease [3]. In the past decade, the role of organ-preservation protocols, with combined chemoradiation and surgery for salvage, has increased. These protocols are particularly effective for patients with moderately advanced cancers of the larynx and pharynx who are less than 70 years old and have a good performance status [2]. Also technical improvements have decreased late radiotherapy side-effects. Recently Nutting and coworkers (2011) compared conventional radiotherapy to parotid-sparing intensity-modulated radiotherapy (IMRT) in patients with pharyngeal squamous cell carcinoma and noticed significantly lower late side-effect rate but did not report any survival advantage [4]. AntiEGFR mAb cetuximab has shown promising antitumour

\section{Ciomed Central}


activity with tolerable toxicity profile but the optimal combinations and schedule is still to be found [5].

The abrogation of $\mathrm{p} 53$ function through the mutation of its gene, TP53 [6], the loss of heterozygosity of TP53 [7] or interaction with viral proteins [8], is one of the most common molecular alterations in squamous-cell carcinoma of the head and neck [9]. The TP53 tumour suppressor gene in chromosome $17 \mathrm{p} 13.1$ encodes the p53 protein, which functions primarily as a multi-target transcription factor. The p53 protein is known to be involved in various cellular functions including cell-cycle regulation, senescence, apoptosis, repair of DNA damage caused by genotoxic agents, angiogenesis, and regulation of oxidative stress and glucose metabolism [10-13]. Loss of the p53 function allows proliferation of the cells with a DNA-damage and promotes neoplasia in transgenic p53 null mice [14]. TP53 gene alterations are commonly found in head and neck cancers, and most of the published mutations affect the p53-DNA interactions, resulting in a partial or complete loss of transactivation functions [15]. TP53 differs from other tumour suppressor genes in its mode of inactivation. While most tumour suppressor genes are inactivated by mutations leading to absence of protein synthesis or production of a truncated protein, more than $80 \%$ of TP53 alterations are missense mutations that lead to the synthesis of a stable full-length protein [15]. The location of the resulting amino-acid substitution is usually within the central DNA-binding domain of the p53, resulting in a loss of DNA-binding activity with consequent failure to transcriptionally activate target genes [16].

In the past 10 years, systematic data from the functional assays have been generated and integrated in the TP53 database managed by the International Agency for Research on Cancer (IARC) (http://www-p53.iarc.fr/) [17]. Most mutant p53 proteins have lost their DNAbinding activity, leading to a loss of their growth inhibiting and apoptotic properties. The role of p53 as a prognostic marker of squamous cell carcinoma of the head and neck is controversial. The possible reasons for this include small numbers of patients studied, insufficient clinical follow-up, variable laboratory techniques used, or analysis of TP53 data based on insufficient mutation characterization $[15,18]$.

In the present study, we pursue the clinical importance of TP53 mutation types in head and neck cancer. We analyzed TP53 mutations in 46 patients with head and neck squamous cell carcinomas (HNSCC) by polymerase chain reaction-single-strand conformation polymorphism (PCR-SSCP) and sequencing as earlier described [19]. The aim of this study was to examine whether specific TP53 mutation types were associated with the clinical outcome of head and neck cancer, such as lymph node metastasis, prognosis and therapy of the patients.

\section{Materials and methods}

Patients and tumours

In this same population, we have investigated earlier p53 aberrations in association with environmental exposures [19]. This study population consists of 46 patients treated for primary head and neck squamous cell carcinoma enrolled as patients in the University Hospital of Oulu, Finland between the years 1994 and 1996. The patients were recruited to the study before any treatment was started. We wanted a long follow-up time to clarify long-time survival differences between specific TP53 mutations. Clinico-pathological variables are given in Table 1 . The age of the patients varied greatly (28-85 years). The stage of the disease, tumour size and lymph node involvement were determined according to the International Union Against Cancer TNM classification (1997) [20]. The histological grade of the tumours were reviewed and classified according to the World Health Organization classification of head and neck tumours [21]. The treatment was carried out according to the stage of the disease and the routine clinical treatment protocol (Table 2). 33 patients received 50 Gy or more

\section{Table 1 Clinicopathological variables}

\begin{tabular}{|c|c|}
\hline Patient characteristics & n \\
\hline All patients & 46 \\
\hline \multicolumn{2}{|l|}{ Sex } \\
\hline Male & 31 \\
\hline Female & 15 \\
\hline \multicolumn{2}{|l|}{ Age, years } \\
\hline$\leq 39$ & 3 \\
\hline $40-65$ & 23 \\
\hline$\geq 66$ & 20 \\
\hline \multicolumn{2}{|l|}{ Anatomical location } \\
\hline Oral cavity & 14 \\
\hline Larynx & 24 \\
\hline Pharynx & 6 \\
\hline Others & 2 \\
\hline \multicolumn{2}{|l|}{ Grade } \\
\hline Grade 1 & 10 \\
\hline Grade 2 & 29 \\
\hline Grade 3 & 7 \\
\hline \multicolumn{2}{|l|}{ TNM classification } \\
\hline $\mathrm{T}_{1-2}$ & 29 \\
\hline$T_{3-4}$ & 17 \\
\hline $\mathrm{N}_{0}$ & 23 \\
\hline $\mathrm{N}_{+}$ & 23 \\
\hline \multicolumn{2}{|l|}{ Stage } \\
\hline 1 & 6 \\
\hline$\|$ & 9 \\
\hline III & 20 \\
\hline IV & 11 \\
\hline
\end{tabular}

Earlier published in Peltonen et al. Head \& Neck Oncology 2010 2:36 [19]. 
Table 2 Features of the primary tumours regarding primary treatment regimen, follow up time and cause of death

\begin{tabular}{|c|c|c|c|c|c|c|c|c|c|}
\hline Tumour & Age & $\begin{array}{l}\text { Disease } \\
\text { site }\end{array}$ & Stage & TP53 gene status & Surgery & $\begin{array}{l}\text { Radiation- } \\
\text { therapy (radical) }\end{array}$ & $\begin{array}{l}\text { Disease free in } \\
\text { months }\end{array}$ & $\begin{array}{l}\text { Overall survival } \\
\text { in months }\end{array}$ & $\begin{array}{l}\text { Death related } \\
\text { to HNSCC }\end{array}$ \\
\hline 1 & 65 & larynx & 2 & wild type & Yes & Yes & 166 & 166 & No \\
\hline 2 & 61 & larynx & 3 & wild type & Yes & Yes & 145 & 145 & No \\
\hline 3 & 56 & pharynx & 3 & $\begin{array}{l}\text { mutation outside L2/ } \\
\text { L3/LSH motif }\end{array}$ & Yes & Yes & 156 & 156 & No \\
\hline 4 & 65 & larynx & 3 & $\begin{array}{l}\text { mutation outside L2/ } \\
\text { L3/LSH motif }\end{array}$ & Yes & Yes & 121 & 121 & No \\
\hline 5 & 48 & pharynx & 3 & wild type & Yes & Yes & & 74 & Yes \\
\hline 7 & 48 & $\begin{array}{l}\text { oral } \\
\text { cavity }\end{array}$ & 3 & wild type & Yes & Yes & 158 & 158 & No \\
\hline 8 & 75 & $\begin{array}{l}\text { oral } \\
\text { cavity }\end{array}$ & 2 & wild type & Yes & Yes & 6 & 15 & Yes \\
\hline 9 & 28 & $\begin{array}{l}\text { oral } \\
\text { cavity }\end{array}$ & 3 & $\begin{array}{l}\text { mutation outside L2/ } \\
\text { L3/LSH motif }\end{array}$ & Yes & Yes & 155 & 155 & No \\
\hline 10 & 58 & $\begin{array}{l}\text { oral } \\
\text { cavity }\end{array}$ & 3 & wild type & Yes & Yes & 11 & 8 & Yes \\
\hline 12 & 78 & $\begin{array}{l}\text { oral } \\
\text { cavity }\end{array}$ & 2 & $\begin{array}{l}\text { mutation in L2/L3/LSH } \\
\text { motif }\end{array}$ & Yes & No & 7 & 40 & Yes \\
\hline 13 & 83 & larynx & 2 & wild-type & Yes & Yes & 51 & 51 & No \\
\hline 14 & 45 & larynx & 1 & wild type & Yes & Yes & 122 & 122 & No \\
\hline 16 & 85 & pharynx & 3 & $\begin{array}{l}\text { mutation in L2/L3/LSH } \\
\text { motif }\end{array}$ & Yes & Yes & 32 & 32 & No \\
\hline 17 & 74 & $\begin{array}{l}\text { oral } \\
\text { cavity }\end{array}$ & 3 & wild type & Yes & No & 3 & 12 & Yes \\
\hline 18 & 72 & larynx & 1 & $\begin{array}{l}\text { mutation outside L2/ } \\
\text { L3/LSH motif }\end{array}$ & Yes & Yes & 164 & 164 & No \\
\hline 19 & 57 & larynx & 4 & $\begin{array}{l}\text { mutation outside L2/ } \\
\text { L3/LSH motif }\end{array}$ & Yes & Yes & 24 & 24 & No \\
\hline 20 & 62 & $\begin{array}{l}\text { oral } \\
\text { cavity }\end{array}$ & 3 & $\begin{array}{l}\text { mutation in L2/L3/LSH } \\
\text { motif }\end{array}$ & No & only palliative & 0 & 1 & Yes \\
\hline 26 & 68 & larynx & 4 & wild type & Yes & Yes & 9 & 18 & Yes \\
\hline 28 & 65 & $\begin{array}{l}\text { oral } \\
\text { cavity }\end{array}$ & 4 & $\begin{array}{l}\text { mutation in L2/L3/LSH } \\
\text { motif }\end{array}$ & No & only palliative & 6 & 22 & Yes \\
\hline 29 & 33 & $\begin{array}{l}\text { oral } \\
\text { cavity }\end{array}$ & 3 & $\begin{array}{l}\text { mutation outside L2/ } \\
\text { L3/LSH motif }\end{array}$ & Yes & Yes & 157 & 157 & No \\
\hline 31 & 71 & $\begin{array}{l}\text { oral } \\
\text { cavity }\end{array}$ & 1 & $\begin{array}{l}\text { mutation in L2/L3/LSH } \\
\text { motif }\end{array}$ & Yes & No & 20 & 84 & Yes \\
\hline 32 & 39 & $\begin{array}{l}\text { oral } \\
\text { cavity }\end{array}$ & 3 & $\begin{array}{l}\text { mutation in L2/L3/LSH } \\
\text { motif }\end{array}$ & Yes & Yes & 37 & 40 & Yes \\
\hline 39 & 68 & larynx & 4 & wild type p53 & Yes & Yes & 11 & 19 & Yes \\
\hline 41 & 53 & nose & 2 & wild type p53 & Yes & Yes & 7 & 18 & Yes \\
\hline 43 & 74 & larynx & 2 & $\begin{array}{l}\text { mutation in L2/L3/LSH } \\
\text { motif }\end{array}$ & No & Yes & 154 & 154 & No \\
\hline 45 & 70 & pharynx & 3 & wild type p53 & Yes & Yes & 142 & 142 & No \\
\hline 46 & 62 & larynx & 1 & $\begin{array}{l}\text { mutation outside L2/ } \\
\text { L3/LSH motif }\end{array}$ & Yes & Yes & 135 & 135 & No \\
\hline 49 & 62 & $\begin{array}{l}\text { oral } \\
\text { cavity }\end{array}$ & 1 & mutation in SSCP & Yes & No & 60 & 67 & Yes \\
\hline 50 & 49 & larynx & 3 & wild type p53 & Yes & Yes & 122 & 122 & No \\
\hline 51 & 63 & larynx & 2 & $\begin{array}{l}\text { mutation outside L2/ } \\
\text { L3/LSH motif }\end{array}$ & Yes & Yes & 109 & 109 & No \\
\hline 52 & 63 & larynx & 4 & wild type p53 & Yes & Yes & 20 & 30 & Yes \\
\hline 53 & 74 & $\begin{array}{l}\text { oral } \\
\text { cavity }\end{array}$ & 4 & $\begin{array}{l}\text { mutation in L2/L3/LSH } \\
\text { motif }\end{array}$ & Yes & No & 35 & 37 & Yes \\
\hline
\end{tabular}


Table 2 Features of the primary tumours regarding primary treatment regimen, follow up time and cause of death (Continued)

\begin{tabular}{|c|c|c|c|c|c|c|c|c|c|}
\hline 54 & 42 & larynx & 3 & $\begin{array}{l}\text { mutation outside L2/ } \\
\text { L3/LSH motif }\end{array}$ & Yes & Yes & 144 & 144 & No \\
\hline 55 & 71 & larynx & 1 & wild type p53 & Yes & Yes & 145 & 145 & No \\
\hline 56 & 59 & larynx & 4 & $\begin{array}{l}\text { mutation in } \mathrm{L} 2 / \mathrm{L} 3 / \mathrm{LSH} \\
\text { motif }\end{array}$ & Yes & Yes & 155 & 155 & Yes \\
\hline 58 & 74 & pharynx & 4 & $\begin{array}{l}\text { mutation outside L2/ } \\
\text { L3/LSH motif }\end{array}$ & No & Yes & 29 & 32 & Yes \\
\hline 59 & 56 & $\begin{array}{l}\text { oral } \\
\text { cavity }\end{array}$ & 3 & wild type p53 & Yes & Yes & 163 & 163 & No \\
\hline 60 & 69 & larynx & 4 & $\begin{array}{l}\text { mutation in L2/L3/LSH } \\
\text { motif }\end{array}$ & Yes & Yes & 22 & 22 & No \\
\hline 61 & 63 & larynx & 3 & $\begin{array}{l}\text { mutation in } \mathrm{L} 2 / \mathrm{L} 3 / \mathrm{LSH} \\
\text { motif }\end{array}$ & No & Yes & 15 & 15 & No \\
\hline 62 & 74 & larynx & 2 & wild type p53 & Yes & Yes & 25 & 25 & No \\
\hline 63 & 69 & larynx & 3 & $\begin{array}{l}\text { mutation in } \mathrm{L} 2 / \mathrm{L} 3 / \mathrm{LSH} \\
\text { motif }\end{array}$ & Yes & No & 5 & 7 & Yes \\
\hline 64 & 56 & larynx & 3 & $\begin{array}{l}\text { mutation in } \mathrm{L} 2 / \mathrm{L} 3 / \mathrm{LSH} \\
\text { motif }\end{array}$ & Yes & Yes & 151 & 151 & No \\
\hline 65 & 75 & larynx & 3 & wild type p53 & Yes & Yes & 20 & 25 & Yes \\
\hline 68 & 76 & pharynx & 4 & SSCP positivity & No & only palliative & 0 & 4 & Yes \\
\hline 69 & 65 & larynx & 2 & $\begin{array}{l}\text { mutation outside L2/ } \\
\text { L3/LSH motif }\end{array}$ & No & Yes & 12 & 43 & Yes \\
\hline 70 & 68 & sinonasal & 4 & wild type p53 & Yes & Yes & 160 & 160 & No \\
\hline
\end{tabular}

radiotherapy as part of their treatment with conventional fractionation, five patients were treated with radical surgical operation without other treatments, and five patients received only radiotherapy (50-64 Gy). No patients were treated with adjuvant chemotherapy. Three of the patients had an advanced carcinoma and received only palliative treatment.

\section{Ethical aspects}

The study design was approved by the local Ethics Committee of the Medical Faculty at the University of Oulu, Finland and a written informed consent was obtained from all patients entering the study.

\section{p53 immunohistochemistry}

Paraffin embedded sections $(4 \mu \mathrm{m})$ from the primary tumours of head and neck carcinomas were stained using the avidin-biotin-immunoperoxidase technique. Paraffin sections were incubated at $37^{\circ} \mathrm{C}$ for at least 4 hours, dewaxed (Histo- Clear ${ }^{\circledR}$, National Diagnostic, Atlanta, GA, USA) and hydrated. Endogenous peroxidase activity was blocked by incubating the slides in $0.1 \%$ hydrogen peroxidase/methanol for $20 \mathrm{~min}$ and non-specific binding was blocked with $10 \%$ goat serum for $15 \mathrm{~min}$. A mouse monoclonal antibody (DO-7, Novocastra Laboratories Ltd., Newcastle upon Tyne, UK) for p53 was used as a primary antibody (1:300) mixed with $1 \%$ bovine serum albumin. The antibody recognizes both wild type and mutant forms of human p53 and the epitope is located between amino acid residues 19 and 26. The specimens were incubated for 60 minutes at room temperature in a humidified chamber after which the immunohistochemical staining was continued using Histostain-bulk kit ${ }^{\circledR}$ (Zymed, San Francisco, CA, USA) according to the manufacturer's protocol. Biotinylated antimouse IgG was used as a secondary antibody and the peroxidase was introduced as a streptavidin conjugate. The slides were washed thoroughly with phosphate-buffered saline between all stages of the procedure. The antibody reaction was visualised by using a fresh substrate solution containing aminoethyl carbazol substrate kit (AEC-kit ${ }^{\circledR}$, Zymed, San Francisco, CA, USA). The sections were counterstained with hematoxylin, dehydrated and mounted in glycerolvinyl-alcohol (GVA mount ${ }^{\circledR}$; Zymed). For negative controls the primary antibody for p53 was replaced with mouse non-immuno IgG and each set of staining always included a separate known positive control sample.

\section{Evaluation of the p53 immunostaining}

The slides were analysed separately by two independent observers blinded from the clinical data. The immunoreactivity in the malignant cells in each section was graded according to the extent and amount of the positive staining from 0 to ++++ . The immunoreactivity in the malignant cells in each section was graded according 
to the number of positively staining nuclei: $<1 \%$ nuclei with a negative reaction, $1 \%>\leq 5 \%$ as,$+>6 \% \leq 10 \%$ as $++>11 \% \leq 40 \%$ as +++ and $>40 \%$ as ++++ .

\section{TP53 mutation analysis strategy}

We analyzed TP53 mutations in exons 5-8, where most of the mutations occur in human tumours (http://wwwp53.iarc.fr/) by using a temperature-controlled nonradioactive single-strand conformation polymorphism (SSCP) analysis [22,23]. A sample was judged to be positive for a TP53 mutation in SSCP only if two independent amplified PCR products contained similar shifted band patterns. Artefacts due to formalin-fixation or the infidelity of the polymerase-enzyme in PCR were ruled out by repeating the analysis. Further characterisation of TP53 mutations was carried out by semi-automatic sequencing: the PCR amplified samples were sequenced with an ABI PRISM 3100 sequencer and BigDye Terminator Sequencing Kit (Applied Biosystems, Foster City, CA).

\section{Amplification of p53 exons by PCR}

Exons 5-8 of the TP53 gene were separately amplified by PCR using two sets of intron primers, the second set internal to the first, i.e. nested primers [24]. The following reagents and concentrations were used in the amplifications: For the primary PCR, formalin-fixed paraffinembedded tumour DNA were used as a template in a total volume of $100 \mu \mathrm{l}$ with $3.0 \mathrm{U}$ of Dynazyme DNA polymerase (Finnzymes, Finland), in a buffer containing $10 \mathrm{mM}$ Tris- $\mathrm{HCl}$ (pH 8.8), $1.5 \mathrm{mM} \mathrm{MgCl}_{2}, 50 \mathrm{mM} \mathrm{KCl}$ and $0.1 \%$ Triton $\mathrm{X}-100,20-40 \mathrm{pmol}$ of each primer and $300 \mu \mathrm{l}$ of dNTPs (Pharmacia Biotech, Finland). The amplification was carried out by 35 cycles including denaturation at $94^{\circ} \mathrm{C}$ for $1 \mathrm{~min}$, annealing at $60^{\circ} \mathrm{C}$ for 1 min and elongation at $78^{\circ} \mathrm{C}$ for 30 seconds. Secondary PCR was done in a total volume of $200 \mu \mathrm{l}$ and $5 \mu \mathrm{l}$ of amplified DNA from the primary PCR was used as a template. To check for possible contamination, the first and the last reactions in each PCR series were controls with no template in the reaction. If a band appeared indicating contamination, the whole series of PCR reactions was disposed of, and the analysis redone. The amplified products were purified by agarose gel electrophoresis, as described earlier [25].

\section{Single-strand conformation polymorphism (SSCP) analysis and sequencing}

A non-radioactive PCR-SSCP method was used as previously described $[19,25]$ with the Pharmacia PhastSystem $^{\circledR}$ semi-dry electrophoresis equipment. Two different temperatures $\left(4^{\circ} \mathrm{C}\right.$ and $\left.20^{\circ} \mathrm{C}\right)$ were used to obtain good efficiency. Several studies have shown that the optimization of SSCP conditions is essential for analytical sensitivity and efficiency (for review see) [26]. Both negative and positive controls were included in each run to ensure the quality of the run. As a negative control, gel-purified, amplified normal TP53 DNA was used. The controls were confirmed to be negative by selecting samples where bands looked the same in SSCP as in former controls, and by additionally sequencing them to confirm the wild-type. As a positive control, DNA was amplified using artificially mutated primers [22]. The gels were stained with silver staining kit (Pharmacia Biotech, Finland) according to the instructions from the manufacturer.

\section{Statistical analysis}

The correlations of tumour stage, TNM classification, histological grade, gender, age, and primary anatomical site were analyzed separately according to the TP53 gene mutations and p53 immunoreactivity. Disease-free time (DFT), disease-specific survival (DSS) and overall survival (OS) were analysed for the HNSCC patients with respect to p53 protein staining and TP53 mutations, using the Kaplan-Meier method and Fisher's exact test. Survival was defined as the time from the date of diagnosis to death due to the cancer or the date of the last follow-up visit. Disease-free time was defined as the time from diagnosis of the cancer to recurrence or death to cancer. Overall survival and disease-specific survival time was calculated from the date of diagnosis until death. The patients were censored on the date of the last follow-up examination or the date of the collection of clinical data, 24/11/2009. Probability values < 0.05 were considered to be statistically significant. All statistical analyses were performed using the SPSS software system (SPSS for Windows, version 16.0, Chicago, IL).

\section{Results}

\section{General outcome}

The mean follow-up of patients was 80 months (range 1-166 mo). At the time of analysis (11/2009), 39\% (18 of $46)$ of the patients had relapsed and died for cancer. Disease-specific 5-year survival was $60.7 \%$ and overall survival $52.2 \%$ for the whole series. Overall 5-year survival was $41.2 \%$ in the group of the patients with a T3 or T4 tumour.

\section{Mutation analysis of TP53 gene}

Judging by SSCP the TP53 gene was mutated in a total of 26 primary tumours (57\%) in the 46 HNSCC patients [19]. Overall, 39 TP53 mutations were identified in these 26 tumours and sequencing was possible in 23 tumour samples. The features of the TP53 mutations are summarized in Table 2. When taking into account the functional and structural domains of p53 as 
described in the IARC TP53 mutation database (http:// www-p53.iarc.fr/) [17]: $22 \%(8 / 36)$ of the mutations affect the L2 domain (between codons 164 and 194), which is needed for the correct folding and stabilization of the central part of the protein, 11\% (4/36) affect the LSH (loop-sheet-helix) motif (codons 119-135 and 272$287)$, and $8 \%(3 / 36)$ affect the L3 domain (between codons 237-250), directly involved in the interaction between the protein and DNA. Details of the characterization of the mutations have been published separately [19].

\section{Comparison of $\mathrm{p} 53$ aberrations with clinical characteristics}

The p53 expression levels, as well as the presence of TP53 mutations were compared with the clinical data. The p53 aberrations have been published previously and they do not associate with histological grade, TNM classification, the stage of the disease or the age of the patients [19]. Furthermore, even when comparing the specific TP53 mutations (e.g. TP53 mutations in DNAbinding domains and TP53 mutations outside those regions) and stage, TNM-classification or tumour histological grade, there was no differences between those two groups.

\section{Disease recurrence and survival of HNSCC patients related to $\mathrm{p} 53$ alterations}

The p53 levels as well as the presence of TP53 mutations were compared with the clinical data. There was no difference in survival or disease recurrence in patients when all TP53 mutations or different grades of p53 expression were taken on account. Patients affected by tumours with TP53 mutations in the DNA-binding domains L2, L3 or LSH, however, had a shorter survival. This trend was also seen when disease-specific death was compared: Patients who had TP53 mutations in L2, L3 and LSH motifs died of cancer more often (7 out of 9 cases, $77.7 \%$ ), than patients with a wild-type p53 in their tumour (8 out of $19,42.1 \%$ ) or patients with tumours presenting a mutation outside L2/L3/LSH domain ( 2 out of 8 cases, $25 \%$ ). We also noticed that patients with TP53 mutations in L3/LSH motif had more node metastases $(83 \%)$ compared to patients with a wild-type tumour (50\%). However, this difference was not statistically significant $(\mathrm{p}=0.2)$. An interesting finding was that the patients with TP53 mutations in DNA binding surface region had a higher number of late residives than the patients with a wild-type p53 or patients with TP53 mutations outside the functional domains of $\mathrm{p} 53$. The patients with TP53 mutations in motifs L2/L3/LSH relapsed more often (eight relapses of 13 cases vs. two relapses of 10 cases) and their disease free survival time was shorter than in other cases (5-yrs rate $20 \%$ vs. $61.5 \%, \mathrm{p}<0.05$, Figure $1 \mathrm{~A}$ ).

Interestingly, patients that had mutations outside the functional domains of TP53 in the primary tumours survived longer than the patients with a wild-type p53 in their tumour. The group of 13 patients with TP53 mutations affecting the DNA-binding domain had a statistically significantly shorter disease-specific survival time (5-yrs survival $43.5 \%$ vs. $77.8 \%, \mathrm{p}<0.05$, Figure 1B) and a trend for a shorter overall survival time at the time for analysis $11 / 2009, \mathrm{p}=0.06$ (5-yrs rate $30.8 \%$ vs. $70.0 \%, \mathrm{p}$ $<0.05$, Figure $1 C$ ) than patients with mutations outside the DNA-binding region. Strong p53 staining was associated with a better disease free time, but no correlation was found between the overall survival and p53 staining.

\section{TP53 mutations and cancer treatment}

The patients with TP53 mutations in L3/LSH motif had significantly poorer response to radiation than patients with a wild type p53 or TP53 mutations outside the DNA-binding regions $(11.4 \%$ vs. $48.6 \%$ vs. $40 \% \mathrm{p}<0.05$, Pearson Chi-Square Test). Moreover, patients with TP53 mutations in important DNA-binding motifs L2, L3, or LSH received less combined treatment (surgery and radiotherapy), compared to patients with a TP53 mutation outside the L2/L3/LSH motif or a wild-type p53 ( $14 \%$ vs. $60.5 \%, \mathrm{p}=0.009)$. On the other hand, patients treated with combined treatment had a longer diseasefree-time (5-years in $71.2 \%$ vs. $37.9 \%, \mathrm{p}<0.05$, Figure $2 \mathrm{~A}$ ), cancer-specific-survival (5-yrs survival $71.6 \%$ vs. $34.2 \%, \mathrm{p}=0.01$, Figure $2 \mathrm{~B}$ ), and overall survival (5-yrs $57.6 \%$ vs. $30.8 \%, \mathrm{p}<0.05$, Figure $2 \mathrm{C}$ ). There was no difference in the treatment modalities between the different age-groups or basic diseases. In groups with different treatment modalities the patient outcome varied: The 5-year disease-specific survival was $75.2 \%$ in the group treated with the preoperative radiotherapy, $69.9 \%$ with postoperative radiotherapy and only $40 \%$ in the group with surgery alone. This difference between the treatment groups almost reached statistical significance $(\mathrm{p}=0.05)$.

\section{Discussion}

In the present study, we have evaluated the prognostic value of TP53 gene aberrations in a series of 46 patients with primary head and neck squamous cell carcinoma. Analysis of TP53 mutations is being studied as a clinical marker [27]. When correlating results from mutation analysis to the outcome in HNSCC, so far restricted to exons 5-8 or 5-9, contradicting results have been published (for reviews see $[28,29]$ ). We found that tumours containing TP53 mutations in DNA-binding surface regions (L2, L3 + LSH) are more 


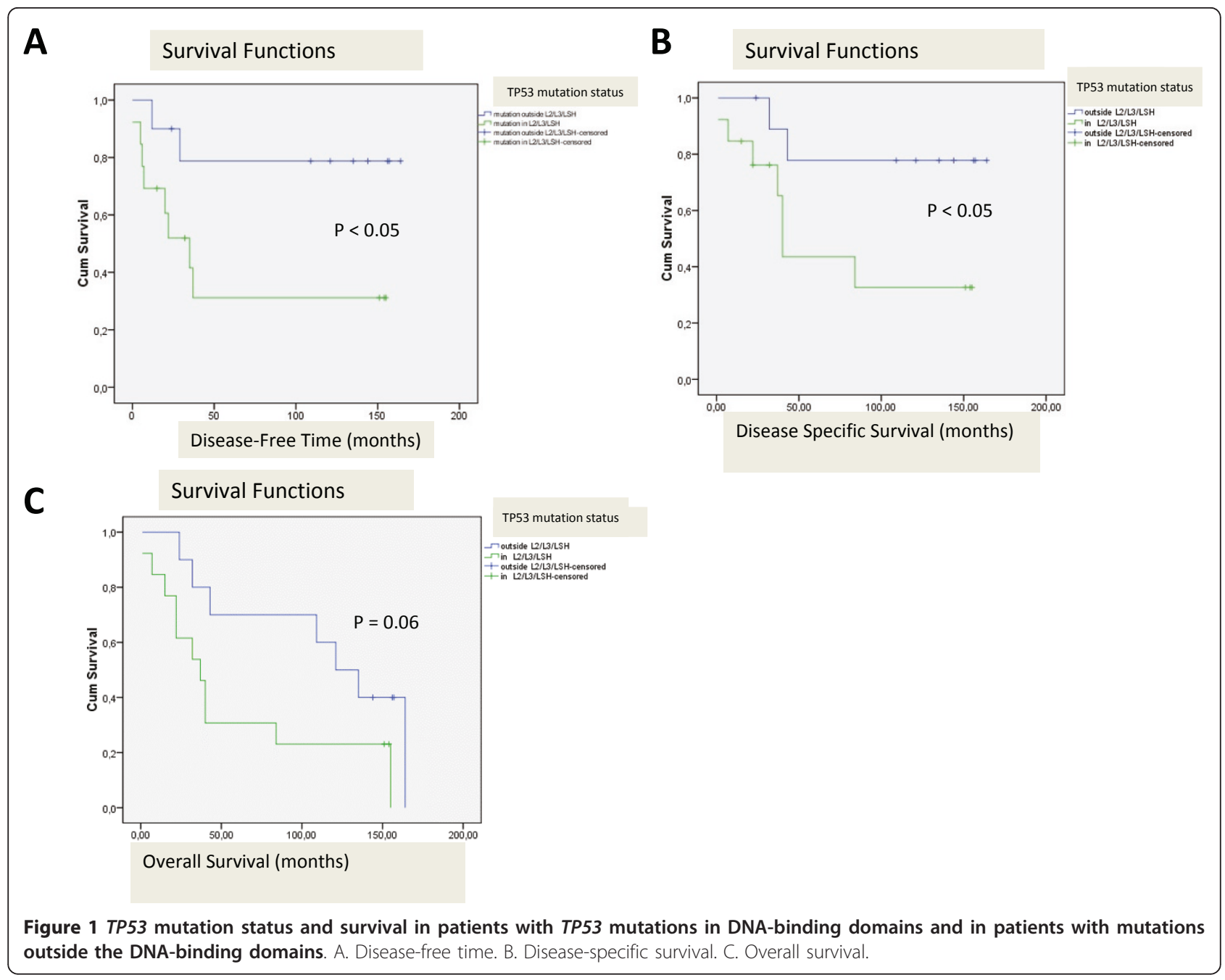

aggressive than tumours with mutations outside of those regions. Interestingly, patients affected by tumours with TP53 mutations in L3 and LSH have poorer survival, and in case of tumours with TP53 mutations in domains L2, L3 + LSH there were more relapses and shorter disease free time than with other tumours implicating a more aggressive phenotype. Similar findings have already been reported in gastric cancer [30], and colorectal carcinoma [31]. Bazan and co-workers (2005) reported that in sporadic colorectal carcinoma tumours with TP53 mutations in L3 domain are associated with a worse prognosis (as judged by disease free time only) than other tumours [31]. Furthermore, several studies have revealed a strong association between the mutations in the L2/L3 loop and a shorter survival or poorer response to treatment in breast cancer [32,33] and in oesophageal cancer [34]. Oral squamous cell cancers with TP53 mutations in DNA-binding surface regions (L2, L3 and the LSH motif) and conserved regions (II-IV) were also associated with a significantly poorer prognosis than tumours with mutations outside of those regions [35]. In a large multi-centre study of squamous cell head and neck cancer, Poeta and co-workers (2007) found that mutations affecting the protein structure and DNA-binding capacity of TP53 were associated with shortened disease-specific and overall survival [36]. In our study, most $(78 \%)$ patients that had TP53 mutations in L2, L3 and LSH motifs died of cancer. Only $42 \%$ of those patients with a wild type TP53 or $12.5 \%$ in those with TP53 mutations outside the L2/L3/LSH domain died of cancer. Interestingly, the patients with mutations outside the DNA-binding domains of p53 had a better survival than the patients with a wild-type p53. The association between TP53 mutation types and outcome presented here is also in agreement with the largest study on the TP53 mutation types and association with clinical phenotypes carried out in 630 patients screened for mutations in breast cancer and published by Alsner and co-workers (2008) [37]. 


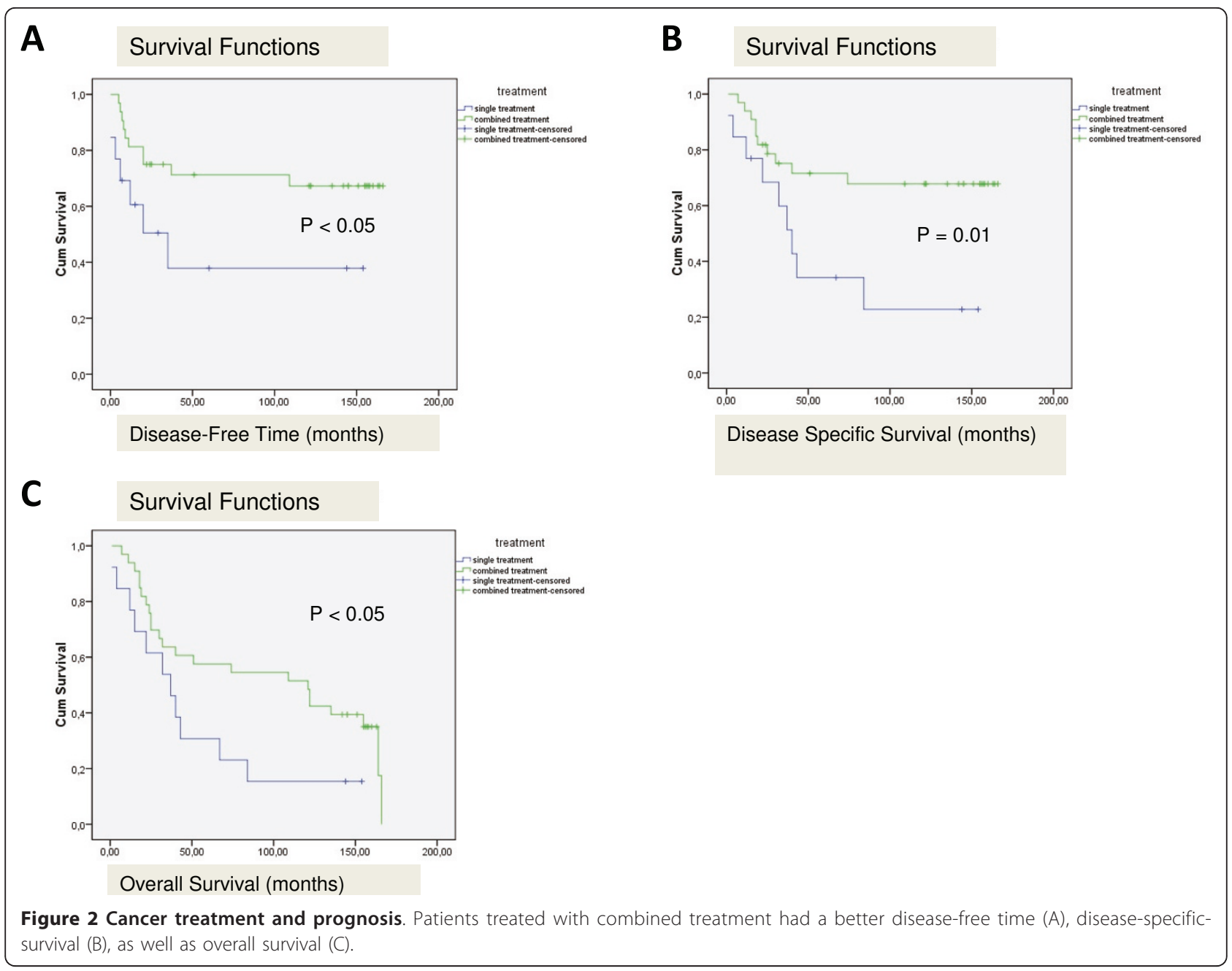

When we compared the disease-free survival, diseasespecific or overall survival in HNSCC patients with and without TP53 mutations, no difference was seen between the two groups. Similarly, some researchers have failed to find such a correlation $[38,39]$. On the other hand, positive association between the TP53 mutations and poor prognosis have been published $[36,40,41]$. Patients with TP53 mutations have been shown to have a significantly shorter survival time than those without any TP53 mutations [42]. Also the locoregional control rate and disease-free survival rate have been shown to be inferior in the patient group with a TP53 mutation when compared to the patients with a wild-type TP53 [43]. We show here that TP53 mutations in exons 6 and 8 correlate with poorer overall survival. Russo and co-workers (2006) have noticed that TP53 mutations within exons 5 and 8 are strong prognostic indicators of both disease recurrence and survival in patients with locally advanced laryngeal squamous cell carcinoma [41]. Similarly, Huang and co-workers (1998) have studied 204 cases of non-small cell lung carcinoma, and patients with mutations in exons 7 and 8 have a significantly shorter survival compared with patients with other mutations or no mutation [44]. Our findings together with the published data suggest that the nature and location of the mutation are connected to tumour aggressiveness and prognosis and it is not enough to analyze merely the presence or absence of the TP53 mutations. Thus, the usefulness of TP53 mutations in human tumours for clinical purposes requires a much more detailed analysis.

We found here that patients with TP53 mutations in L2, L3 or LSH motif received significantly less often combined treatment (curative intent) and had significantly lower disease-free time and cancer specific-survival. Therefore, specific TP53 mutations present in L2, L3 and LSH motifs could lead to inherently more aggressive tumours than mutations outside of these regions. The age of the patients or other diseases did not affect the treatment modalities. Mechanism of 
action of a mutant p53 appears to be complex $[45,46]$. Many studies have shown that although mutant p53 proteins often lose the ability to activate the expression of genes that are responsive to wild-type p53, they may not be inert when it comes to the regulation of transcription [16]. Indeed, a mutant p53 can acquire the ability to both positively and negatively regulate gene expression, which clearly contributes to some of the pro-tumorigenic functions of a mutant $\mathrm{p} 53$, such as enhanced survival and resistance to cancer therapy $[16,47]$.

There have been a limited number of inconclusive studies on TP53 mutations in patients treated with primary radiotherapy (for a review, see [48]). We evaluated the relationship between TP53 mutations and radiosensitivity in 36 patients with HNSCC who underwent primary radiotherapy. Tumours containing TP53 mutations in DNA-binding surface region had significantly poorer responses to radiation than other tumours. Eriksen and co-workers (2005) have investigated the importance of TP53 mutations for the overall treatment time of radiotherapy in HNSCC patients [39]. They noticed that patients with carcinomas containing a wild-type p53 did not benefit as much as the patients with a mutated TP53 from an increase in the number of weekly fractions (i.e. a reduction in the overall treatment time), as judged by local control at T-site, disease-specific or crude survival [39]. This may be due to the decreased ability of some mutant p53 proteins to initiate apoptosis [49]. Consequently, there may be less delay in G1 resulting in increased progress through the cell cycle and increased uncontrolled proliferation [39]. Moreover, Alsner and co-workers (2001b) noticed that majority of head and neck of tumours with a mutated TP53 had a tumour potential doubling time below that in wild typetumours [50]. Carcinomas with a mutated TP53 had higher cell proliferation potential compared to wild type-tumours. TP53 mutation status may thus identify patients where the dominating factor associated with outcome is an increased intrinsic radioresistance.

\section{Conclusions}

In conclusion, this study demonstrates that the clinical outcome for head and neck cancer patients is associated with the type of TP53 mutations. Mutations present in DNA-binding regions were associated with poorer prognosis and clinical response to radiotherapy. Especially, TP53 mutations in L2 and L3 + LSH motif may be usable as a marker for selecting the treatment option and predicting prognosis among HNSCC. Predictive factors become increasingly important, in particular because new treatment modalities e.g. radiotherapy combined with EGFR generally yield more treatment-related toxicity. However, due to the small number of patients in this study further confirmation is required before reliable clinical application is possible. Studies are needed to evaluate whether specific TP53 mutations influence prognosis in patients treated with conventional chemoradiotherapy or radiotherapy combined with anti-EGFR treatment.

\section{Acknowledgements}

The authors thank Ms. Virpi Koponen, Ms. Kaisu Järvenpää, Ms. Anne Bisi, Ms. Tuulikki Kärnä and Ms. Kaisa Penttilä for skillful technical assistance, Mr. Kari Mononen for help in collecting some of the clinical data and Ms. Anne Väisänen for critical reading of this manuscript. The work has been financially supported by K. Albin Johansson Foundation and the Finnish Medical Foundation, and at earlier stages by the Finnish Academy.

\section{Author details}

'Department of Oncology and Radiotherapy, Oulu University Hospital, University of Oulu, Oulu, Finland. ${ }^{2}$ Department of Pharmacology and Toxicology, University of Oulu, Finland. ${ }^{3}$ Faculty of Health Sciences, University of Eastern Finland, Kuopio, Finland. ${ }^{4}$ Medical Informatics Group, University of Oulu, Finland. ${ }^{5}$ Institution of Diagnostic, Department of Pathology, University of Oulu, Oulu University Hospital, Finland.

\section{Authors' contributions}

JKP carried out mutation analysis, and outcome data and wrote the paper with T-TH. KHV took part in designing and supervising the study, took part in the mutation analysis, and commented and edited the manuscript. $\mathrm{HMH}$ carried out immunohistochemical analysis and statistical analysis, and commented the manuscript. PP provided pathology expertise, carried out immunohistological analysis and commented the manuscript. RB helped with statistical analysis and corrected statistical data. T-TH took part in designing the study, was responsible for identifying the patients, designed and supervised the study, wrote the manuscript with JKP. All authors approved the final manuscript.

\section{Competing interests}

The authors declare that they have no competing interests.

Received: 18 February 2011 Accepted: 22 April 2011

Published: 22 April 2011

\section{References}

1. Argiris A, Karamouzis MV, Raben D, Ferris RL: Head and neck cancer. Lancet 2008, 371:1695-709.

2. Leemans CR, Braakhuis BJM, Brakenhoff $\mathrm{RH}$ : The molecular biology of head and neck cancer. Nat Rev Cancer 2011, 11:9-22.

3. Langendijk JA, Ferlito A, Takes RP, Rodrigo JP, Suárez C, Strojan P, Haigentz M Jr, Rinaldo A: Postoperative strategies after primary surgery for squamous cell carcinoma of the head and neck. Oral Oncol 2010, 46:577-85.

4. Nutting CM, Morden JP, Harrington KJ, Urbano TG, Bhide SA, Clark C, Miles EA, Miah AB, Newbold K, Tanay M, Adab F, Jefferies SJ, Scrase C, Yap BK, A'Hern RP, Sydenham MA, Emson M, Hall E, PARSPORT trial management group: Parotid-sparing intensity modulated versus conventional radiotherapy in head and neck cancer. (PARSPORT): a phase 3 multicentre randomised controlled trial. Lancet Oncol 2011, 12:127-36.

5. Sundvall M, Karrila A, Nordberg J, Grénman R, Elenius K: EGFR targeting drugs in the treatment of head and neck squamous cell carcinoma. Expert Opin Emerg Drugs 2010, 15:185-201.

6. Hainaut $P$, Hollstein M: p53 and human cancer: the first ten thousand mutations. Adv Cancer Res 2000, 77:81-137.

7. Graveland AP, Golusinski PJ, Buijze M, Douma R, Sons N, Kuik DJ, Bloemena E, Leemans CR, Brakenhoff RH, Braakhuis BJ: Loss of heterozygosity at $9 p$ and immunopositivity in surgical margins predict local relapse in head and neck squamous cell carcinoma. Int J Cancer 2011, 128:1852-9.

8. Dayyani F, Etzel CJ, Liu M, Ho CH, Lippman SM, Tsao AS: Meta-analysis of the impact of human papillomavirus (HPV) on cancer risk and overall 
survival in head and neck squamous cell carcinomas (HNSCC). Head and Neck Oncol 2010, 2:15.

9. Gasco M, Crook T: The p53 network in head and neck cancer. Oral Oncol 2003, 39:222-31.

10. Komarova EA, Krivokrysenko V, Wang K, Neznanov N, Chernov MV, Komarov PG, Brennan ML, Golovkina TV, Rokhlin O, Kuprash DV, Nedospasov SA, Hazen SR, Feinstein E, Gudkov AV: p53 is a suppressor of inflammatory response in mice. FASEB $J$ 2005, 19:1030-2.

11. Sengupta S, Harris CC: p53: traffic cop at the crossroads of DNA repair and recombination. Nat Rev Mol Cell Biol 2005, 6:44-55.

12. Hussain SP, Harris CC: p53 biological network: at the crossroads of the cellular-stress response pathway and molecular carcinogenesis. J Nippon Med Sch 2006, 73:54-64.

13. Bensaad K, Vousden KH: p53: new roles in metabolism. Trends Cell Biol 2007, 17:286-91.

14. Donehower LA, Harvey M, Slagle BL, MCArthur MJ, Montgomery CA Jr, Butel JS, Bradley A: Mice deficient for $\mathrm{p} 53$ are developmentally normal but susceptible to spontaneous tumours. Nature 1992, 356:215-21.

15. Soussi T, Béroud C: Assessing TP53 status in human tumors to evaluate clinical outcome. Nat Rev Cancer 2001, 1:233-40.

16. Vousden KH: Functions of $\mathrm{p} 53$ in metabolism and invasion. Biochem Soc Trans 2009, 37:511-7.

17. The IARC TP53 mutation database:[http://www-p53.iarc.fr].

18. Robles Al, Harris CC: Clinical outcomes and correlates of TP53 mutations and cancer. Cold Spring Harb Perspect Biol 2010, 2(3):a001016.

19. Peltonen JK, Helppi HM, Pääkkö P, Turpeenniemi-Hujanen T, Vähäkangas $\mathrm{KH}$ : p53 in head and neck cancer: functional consequences and environmental implications of TP53 mutations. Head Neck Oncol 2010, 2:36.

20. International Union Against Cancer: TNM classification of malignant tumors Geneva, Switzerland: Wiley-Liss; 1997, 7-49.

21. Barnes L, Eveson JW, Reichart P, Sidransky D, (Eds): Pathology and Genetics of Head and Neck Tumours Lyon: World Health Organization Classification of Tumours. IARC Press; 2005

22. Welsh JA, Castren K, Vähäkangas KH: Single-strand conformation polymorphism analysis to detect p53 mutations: characterization and development of controls. Clin Chem 1997, 43:2251-5.

23. Vähäkangas KH, Castren K, Welsh JA: Single-strand conformation polymorphism analysis of mutations in exons 4-8 of the TP53 gene. Meth Mol Med 2000, 49:15-27.

24. Lehman TA, Bennett WP, Metcalf RA, Welsh JA, Ecker J, Modali RV, Ullrich S, Romano JW, Appella E, Testa JR, Gerwin BE, Harris CC: p53 mutations, ras mutations, and p53-heat shock 70 protein complexes in human lung carcinoma cell lines. Cancer Res 1991, 51:4090-6.

25. Hakkarainen J, Welsh JA, Vähäkangas KH: TP53 mutation detection by SSCP and sequencing. In Molecular diagnosis of cancer. Volume 97.. 2 edition. Edited by: Roulston JE \& Bartlett JMS. Totowa, New Jersey: Humana Press Inc; 2004:191-208, Methods in Molecular Medicine.

26. Peltonen J, Welsh JA, Vähäkangas KH: Is there a role for PCR-SSCP among the methods for missense mutation detection of TP53 gene. Hum Exp Toxicol 2007, 26:9-18

27. Seemann S, Maurici D, Olivier M, de Fromentel CC, Hainaut P: The tumor suppressor gene TP53: Implication for cancer management and therapy. Crit Rev Clil Lab Sci 2004, 41:551-583.

28. Nylander K, Dabelsteen E, Hall PA: The p53 molecule and its prognostic role in squamous cell carcinomas of the head and neck. J Oral Pathol Med 2000, 29:413-25.

29. Lothaire $P$, de Azambuja E, Dequanter D, Lalami $Y$, Sotiriou C, Andry G, Castro G Jr, Awada A: Molecular markers of head and neck squamous cell carcinoma: promising signs in need of prospective evaluation. Head Neck 2006, 28:256-69.

30. Migliavacca M, Ottini L, Bazan V, Agnese V, Corsale S, Macaluso M, Lupi R, Dardanoni G, Valerio MR, Pantuso G, Di Fede G, Tomasino RM, Gebbia N, Mariani-Costantini R, Russo A: TP53 in gastric cancer: Mutations in the L3 loop and LSH motif DNA-binding domains of TP53 predict poor outcome. J Cell Physiol 2004, 200:476-85.

31. Bazan V, Agnese V, Corsale S, Calo V, Valerio MR, Latteri MA, Vieni S, Grassi N, Cicero G, Dardanoni G, Tomasino RM, Colucci G, Gebbia N, Russo A, Gruppo Oncologico dell'Italia Meridionale (GOIM): Specific TP53 and/or Ki-ras mutations as independent predictors of clinical outcome in sporadic colorectal adenocarcinomas: results of a 5-year Gruppo
Oncologico dell'Italia Meridionale (GOIM) prospective study. Ann Oncol 2005, 16:iv50-iv55.

32. Nagai MA, Schaer Barbosa $H$, Zago MA, Araújo Silva W Jr, Nishimoto IN, Salaorni S, Guerreiro Costa LN, Silva Araújo M, Caldas Oliveira AG, Mourâo Neto M, Brentani MM: TP53 mutations in primary breast carcinomas from white and African-Brazilian patients. Int J Oncol 2003, 23:189-96.

33. Geisler S, Lønning PE, Aas T, Johnsen H, Fluge O, Haugen DF, Lillehaug JR, Akslen LA, Børresen-Dale AL: Influence of TP53 gee alterations and cerbB-2 expression on the response to treatment with doxorubisin in locally advanced breast cancer. Cancer Res 2001, 61:2505-12.

34. Kihara C, Seki T, Furukawa Y, Yamana H, Kimura Y, van Schaardenburgh P, Hirata K, Nakamura Y: Mutations in zinc-binding domains of $\mathrm{p} 53$ as a prognostic marker of esophageal cancer patients. Jpn J Cancer Res 2000, 91:190-8.

35. Yamazaki Y, Chiba I, Hirai A, Sugiura C, Notani K, Kashiwazaki H, Tei K, Totsuka Y, Fukuda H: Specific p53 mutations predict poor prognosis in oral squamous cell carcinoma. Oral Oncol 2003, 39:163-9.

36. Poeta ML, Manola J, Goldwasser MA, Forastieri A, Benoit N, Califano JA, Ridge JA, Gooswin J, Kenady D, Saunders J, Westra W, Sidransky D, Koch WM: TP53 mutations and survival in squamous cell carcinoma of the head and neck. N Engl J Med 2007, 357:2552-61.

37. Alsner J, Jensen V, Kyndi M, Offersen BV, Vu P, Børresen-Dale AL, Overgaard J: A comparison between p53 accumulation determined by immunohistochemistry and TP53 mutations as prognostic variables in tumours from breast cancer patients. Acta Oncol 2008, 47:600-7.

38. Bosch FX, Ritter D, Enders C, Flechtenmacher C, Abel U, Dietz A, Hergenhahn M, Weidauer $\mathrm{H}$ : Head and neck tumor sites differ in prevalence and spectrum of $\mathrm{p} 53$ alterations but these have limited prognostic value. Int J Cancer 2004, 111:530-8.

39. Eriksen JG, Alsner J, Steiniche T, Overgaard J: The possible role of TP53 mutation status in the treatment of squamous cell carcinomas of the head and neck (HNSCC) with radiotherapy with different overall treatment times. Radiother Oncol 2005, 76:135-42.

40. Sisk EA, Soltys SG, Zhu S, Fisher SG, Carey TE, Bradford CR: Human papillomavirus and p53 mutational status as prognostic factors in head and neck carcinoma. Head Neck 2002, 24:841-9.

41. Russo A, Corsale S, Agnese V, Macaluso M, Cascio S, Bruno L, Surmacz E, Dardanoni G, Valerio MR, Vieni S, Restivo S, Fulfaro F, Tomasino RM, Gebbia N, Bazan V: TP53 mutations and S-phase fraction but not DNAploidy are independent prognostic indicators in laryngeal squamous cell carcinoma. J Cell Physiol 2006, 206:181-8.

42. Obata A, Eura M, Sasaki J, Saya H, Chikamatsu K, Tada M, Iggo RD, Yumoto E: Clinical significance of $p 53$ functional loss in squamous cell carcinoma of the oropharynx. Int J Cancer 2000, 89:187-93.

43. Alsner J, Sørensen SB, Overgaard J: TP53 mutation is related to poor prognosis after radiotherapy, but not surgery, in squamous cell carcinoma of the head and neck. Radiother Oncol 2001, 59:179-85.

44. Huang C, Taki T, Adachi M, Konishi T, Higashiyama M, Miyake M: Mutations in exon 7 and 8 of $p 53$ as poor prognostic factors in patients with nonsmall cell lung cancer. Oncogene 1998, 16:2469-77.

45. Petitjean A, Achatz MIW, Børresen-Dale AL, Hainaut P, Olivier M: TP53 mutations in human cancers: functional selection and impact on cancer prognosis and outcomes. Oncogene 2007, 26:2157-65.

46. Olivier M, Petitjean A, Marcel V, Pétré A, Mounawar M, Plymoth A, de Fromentel CC, Hainaut P: Recent advantages in $\mathrm{p} 53$ research: an interdisciplinary respective. Cancer Gene Ther 2009, 16:1-12.

47. Weisz $L$, Oren $M$, Rotter V: Transcription regulation by mutant $p 53$. Oncogene 2007, 26:2202-11.

48. Silva P, Homer JJ, Slevin NJ, Musgrove BT, Sloan P, Price P, West CML: Clinical and biological factors affecting response to radiotherapy in patients with head and neck cancer: a review. Clin Otolaryngol 2007, 32:337-45

49. Fei P, El-Deiry WS: P53 and radiation response. Oncogene 2003, 22:5774-83.

50. Alsner J, Hoyer M, Sørensen SB, Overgaard J: Interaction between potential doubling time and TP53 mutation: predicting radiotherapy outcome in squamous cell carcinoma of the head and neck. Int I Radiat Oncol Biol Phys 2001, 49:519-25.

doi:10.1186/1758-3284-3-20

Cite this article as: Peltonen et al: Specific TP53 mutations predict aggressive phenotype in head and neck squamous cell carcinoma: retrospective archival study. Head \& Neck Oncology 2011 3:20. 